\title{
STRUCTURE AND DYNAMICS OF PYRENE-LABELED POLY(ACRYLIC ACID): MOLECULAR DYNAMICS SIMULATION STUDY
}

\author{
Maria Slavgorodska1, Alexander Kyrychenko ${ }^{1, \otimes}$
}

https://doi.org/10.23939/chcht14.01.076

\begin{abstract}
An atomistic model for molecular dynamics (MD) simulations of the single chain poly(acrylic acid) (PAA), terminally substituted with two pyrene moieties, was developed. MD simulations of the structure and conformational dynamics of pyrene-labeled PAA for a varying dissociation degree $(\alpha)$ of the $\mathrm{COOH}$ group revealed that the attachment of pyrene dyes to PAA alters significantly its conformational behavior. At acidic $\mathrm{pH}$ $(\alpha=0)$, the PAA chain collapsed into the random coil conformation, so that the two pyrene moieties formed the stable $\pi-\pi$ stacking structure. However, at basic $\mathrm{pH}$ $(\alpha=1)$, the PAA chain was expanded and stretched facing the pyrene dyes apart into aqueous solution.
\end{abstract}

Keywords: poly(acrylic acid), pyrene, fluorescent probe, conformational dynamics, molecular dynamics simulations.

\section{Introduction}

Water-soluble pH-responsive polymers, labeled covalently with fluorescent dyes, have attracted a major focus of interest in polymer photophysics due to their stimuli-responsive self-organizing behavior [1-3]. They have revealed numerous important applications for surface modification, structuring and, in particular, rheology control [1]. Among the most studied cases are the polyelectrolytes, such as poly(acrylic acid) (PAA), randomly labeled with aromatic fluorophores (e.g., naphthalene, pyrene, perylene) [4-7]. Numerous experimental studies of $\mathrm{pH}$-dependent behavior of chemically linked pyrene fluorescent units to the PAA backbone have been reported $[4,8,9]$.

The polymer chain conformation and the photophysical behavior of poly(acrylic acids) randomly labeled with pyrene have been studied by using steadystate and time-resolved fluorescence spectroscopy [10,

\footnotetext{
${ }^{1}$ V. N. Karazin Kharkiv National University, 4, Svobody Sq., 61022 Kharkiv, Ukraine

凶a.v.kyrychenko@karazin.ua

(c) Slavgorodska M., Kyrychenko A., 2020
}

11]. The concurrent increase in excimer emission upon the increase in polymer concentration was used to monitor interpolymer association between pyrene groups to form the dimeric excited state [9, 12].Beside studies of conformational heterogeneity of pyrene-labeled PAA, non-radiative excitation energy transfer among pyrene units has also been reported [5]. In addition, it has been shown that the $\mathrm{pH}$-responsive amphiphilic pyrenefunctionalized polymers were able to self-assemble into polymeric nanoparticles in water [13]. Moreover, PAAbased polymeric nanoparticles have recently been used to design novel drug-delivery nanocontainers having $\mathrm{pH}$ tunable and reversible encapsulation of pharmaceutically relevant compounds [14-18].

Therefore, studying toward a better understanding of the role of dye-modification in the polymer dynamics and self-assembly will ultimately lead to a better understanding of the fundamental physicochemical properties of $\mathrm{pH}$-responsive polyelectrolytes [19]. The goal of this work is the development and validation of an atomistic MD model for pyrene-labeled PAA (Fig. 1), focusing on systematical investigating of the conformational behavior of PAA as a function of the degree of dissociation of the carboxylic groups.

\section{Experimental}

\subsection{Poly(Acrylic Acid) Force Field}

Poly(acrylic acid) and its derivatives such as poly(methyl acrylic) (PMA) and poly(ethyl acrylic) (PEA) acids are of particular interest because of their use as models of polyelectrolytes and organic polyacids, which play a major role in many physicochemical processes in aqueous systems, so that they have computationally been investigated from a microscopic viewpoint [20-22]. Numerous MD simulations studied were performed for oligomers of PAA and its derivatives of different tacticities, molecular weights, degrees of deprotonation, and deprotonation patterns by using all-atom FF such as 
OPLS-AA [23] and CHARMM27 [22]. In addition, an important role of salt effects and counter ion valence in the conformation behavior of PAA has also been considered [24, 25]. In the recent study [26], static and dynamics light scattering measurements were combined with coarse-grained MD simulations of the chain extension and hydrodynamic radius $\left(R_{g}\right)$ of the sodium salt of poly(acrylic acid) (Na-PAA). A role of $\mathrm{pH}$ and ionic strength in polymer conformation of $\mathrm{PAA}_{n}$ with large molecular weight $\left(M_{w}\right.$ and $n$ reached up to $50 \mathrm{kDa}$ and 700 units, respectively) has been studied by using the fluorescence correlation spectroscopy and Monte Carlo simulations [23]. Finally, self-association behavior of oligomers of PAA has also been modeled [27, 28]. Recently, Sulatha and Natarajan [29] have adopted the GROMOS G53a6 united atom FFs suitable for MD simulations of a single chain PAA oligomer in water.

(a)<smiles>CCC(CC1CC1C(=O)O)C(=O)[O-]</smiles>

PAA

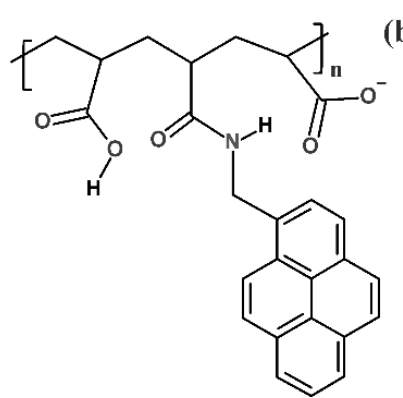

Fig. 1. Structure of poly(acrylic acid) (a) and pyrene-labeled poly(acrylic acid) (b)

For better understanding of the structure and conformational dynamics of PAA, we developed an atomistic MD model of poly(acrylic acid) $\left(\mathrm{PAA}_{40}\right)$, peripherally labeled with the two pyrene units (Fig. 1). The PAA model and FF interaction parameters were adopted from the recent work by Sulatha and Natarajan [29], in which the G53a6 united atom FF [27] was suggested as the most reliable for MD simulations of PAA oligomers in a diluted aqueous solution. In G53a6, the $\mathrm{CH}, \mathrm{CH}_{2}$ and $\mathrm{CH}_{3}$ moieties are treated as a single united interacting site (Fig. 1). The bond length and angle parameters for a pyrene dye were optimized by DFT calculations at the B3LYP/cc-pVDZ level. Partial charges needed for Coulomb interactions were derived from the B3LYP/cc-pVDZ electron densities by fitting the electrostatic potential to point (ESP) charges.

A single chain of $\mathrm{Py}_{2}-\mathrm{PAA}_{38}$ was built by randomly assigning tacticity and backbone dihedral conformations (Fig. 2). In order to randomize the structure and to relax local stresses further, the chain was subjected to steepest descent energy minimization and $200 \mathrm{ps}$ molecular dynamics pre-equilibration of the polymer in vacuum, as described earlier [30, 31].

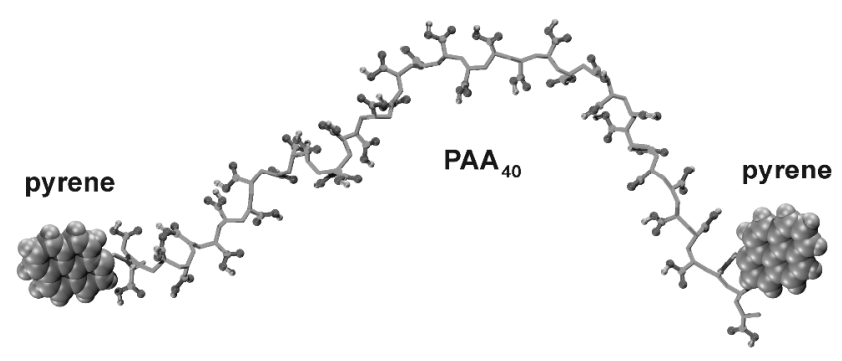

Fig. 2. MD snapshot of the initial conformation of $\mathrm{Py}_{2}-\mathrm{PAA}_{38}$ with $\alpha=0$. The pyrene dyes were substituted at the residues 3 and 38 , respectively

\subsection{Molecular Dynamics Setup}

The systems were solvated by 17200 explicit water molecules using the Simple Point Charge (SPC/E) water model [32], compatible with the G53a6 FF. The size of the water box was chosen to ensure that the systems have at least $15 \AA$ solvation shell from the outermost PAA atoms in all directions. To keep the electro neutrality of the system, sodium ions $\mathrm{Na}^{+}$were added to aqueous solution. All the MD simulations were carried out at a constant number of particles, constant pressure of $P=$ $101.3 \mathrm{kPa}$, and constant temperature $T=298 \mathrm{~K}$ (the NPT ensemble). Solvent (water, ions $\mathrm{Na}^{+}$) and PAA were each coupled separately to a heat bath at the reference temperature of $298 \mathrm{~K}$, which was kept constant using the velocity rescaling weak coupling scheme [33] with a coupling constant $\tau=0.1 \mathrm{ps}$.

The initial atomic velocities were generated with a Maxwellian distribution at the given absolute temperature. Periodic boundary conditions were applied to all three directions of the simulated box. Electrostatic interactions were simulated with the particle mesh Ewald (PME) approach [34] using the long-range cutoff of $0.8 \mathrm{~nm}$. The cutoff distance of the Lennard-Jones interactions was also equal to $0.8 \mathrm{~nm}$. The MD simulation time step was $2 \mathrm{fs}$ with the neighbor list updates every $10 \mathrm{fs}$. All bond lengths in PVA were kept constant using the LINCS routine $[35,36]$. The $\mathrm{MD}$ simulations were carried out using the GROMACS set of programs, version 4.6.5 [37]. Molecular graphics and visualization were performed using VMD 1.9.2 [38]. 


\section{Results and Discussion}

\subsection{Conformational Dynamics of $\mathrm{Py}_{2}-\mathrm{PAA}_{38}$ as a Function of $\mathrm{pH}$}

A pyrene probe has been used as a fluorescent label in chemistry and biology $[6,39]$. To get an insight into the conformational behavior of $\mathrm{Py}_{2}-\mathrm{PAA}_{38}$ as a function of $\mathrm{pH}$, we studied its equilibrium conformations by $\mathrm{MD}$ simulations. The degree of protonation was varied from 0 to 1 to investigate the effect of protonation of the carboxyl group on the conformational state of PAA, where the groups $-\mathrm{COOH}$ were fully protonated $(\alpha=0)$ or unprotonated $(\alpha=1)$, respectively. According to the $\mathrm{pK}_{\mathrm{a}}$ value of PAA, the $\mathrm{COOH}$ groups almost appear in the form of protonation and deprotonation under acidic conditions $(\mathrm{pH}<3)$ and basic conditions $(\mathrm{pH}>11)$, respectively [40].

Fig. 3 shows representative MD conformations of $\mathrm{Py}_{2}-\mathrm{PAA}_{38}$ obtained after $120 \mathrm{~ns}$ of MD sampling. As seen, compact globule conformations of PAA were observed at $\alpha=0-0.3$. The PAA collapsed into the compact globule, in which the hydrophobic moiety of a pyrene dye could be located. Upon an increase in $\alpha$ value to $0.4-0.6$, as a consequence of the progressive ionization of the carboxylic $(\mathrm{COOH})$ groups, the electrostatic repulsion between the carboxylate $\left(\mathrm{COO}^{-}\right)$ groups leads to stretching of the polymer chain, which affects the distance between terminal pyrene groups (Fig. 3). Extended coil conformations of $\mathrm{Py}_{2}-\mathrm{PAA}_{38}$ were dominant at $\alpha>0.7$.

\subsection{Radius of Gyration}

To monitor the compactness of a polymer chain, the radius of gyration of PAA was calculated according to Eq. (1):

$$
R_{g}=\sqrt{\frac{\sum_{i}\left\|r_{i}\right\|^{2} m_{i}}{\sum_{i} m_{i}}}
$$

where $m_{i}$ is the mass of atom $i$ and $r_{i}$ the position of atom $i$ with respect to the center of mass of the molecule [41]. Therefore, $R_{g}$ represents the dimension of a polymer chain as calculated by averaging of the mass-weighted distance of each atom from the center-of-mass position of the polymer $[19,42]$.

Our MD simulation results revealed that in the case of unlabeled-PAA, the mean values of $R_{g}$ increases with the increase in $\alpha$. When $\alpha$ approaches 0.5 and $\mathrm{pH}$ reaches 6-7, a PAA macromolecule becomes charged, so that long-range electrostatic interactions become strong enough to extend conformations of the polymer backbone and to increase the values $R_{g}$ (Fig. 4a). However, the further increase in $\alpha$ leads to some decrease in $R_{g}$ of unlabeled-PAA because of counterion condensations and the polyelectrolyte chain collapse [17]. These results agree with the conformational behavior of PAA of similar sizes $(n=20-30)$, which were previously reported $[23,29,40]$. However, our MD simulations of pyrene-labeled $\mathrm{Py}_{2}-\mathrm{PAA}_{38}$ suggest that the attachment of a pyrene dye to PAA alters significantly its conformational behavior. Fig. 4a shows that the $R_{g}$ values of unlabeled and pyrene-labeled PAA agree well for $\alpha>0.7$. In contrast, for $\alpha<0.7$, the hydrophobic pyrene substituents favor more compact structure of the PAA macromolecule (Figs. 3 and 4a).

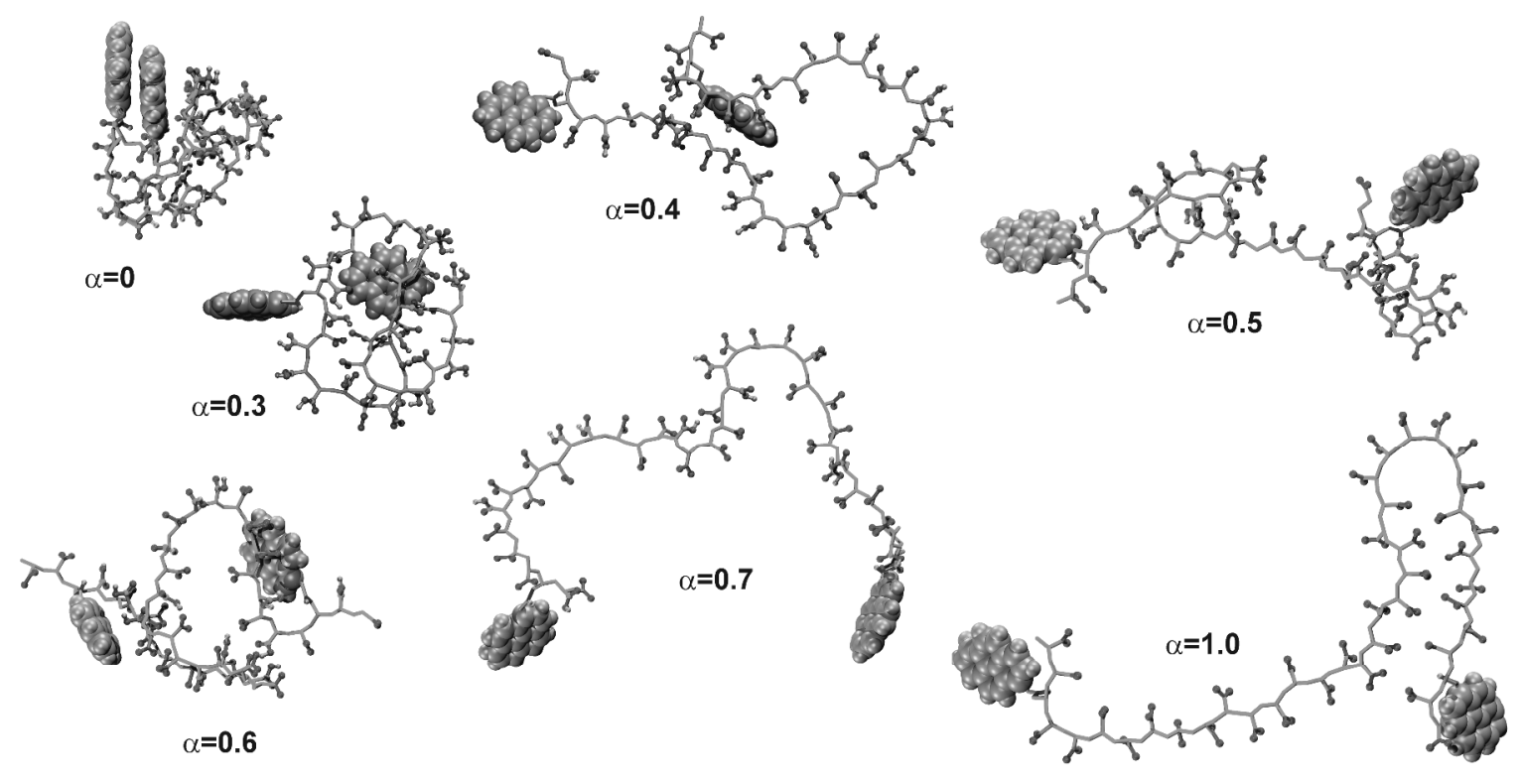

Fig. 3. MD snapshots of the equilibrium conformation of $\mathrm{Py}_{2}-\mathrm{PAA}_{38}$ taken for different $\alpha$ after $120 \mathrm{~ns}$.

The pyrene dyes are shown in the vdW-representation 

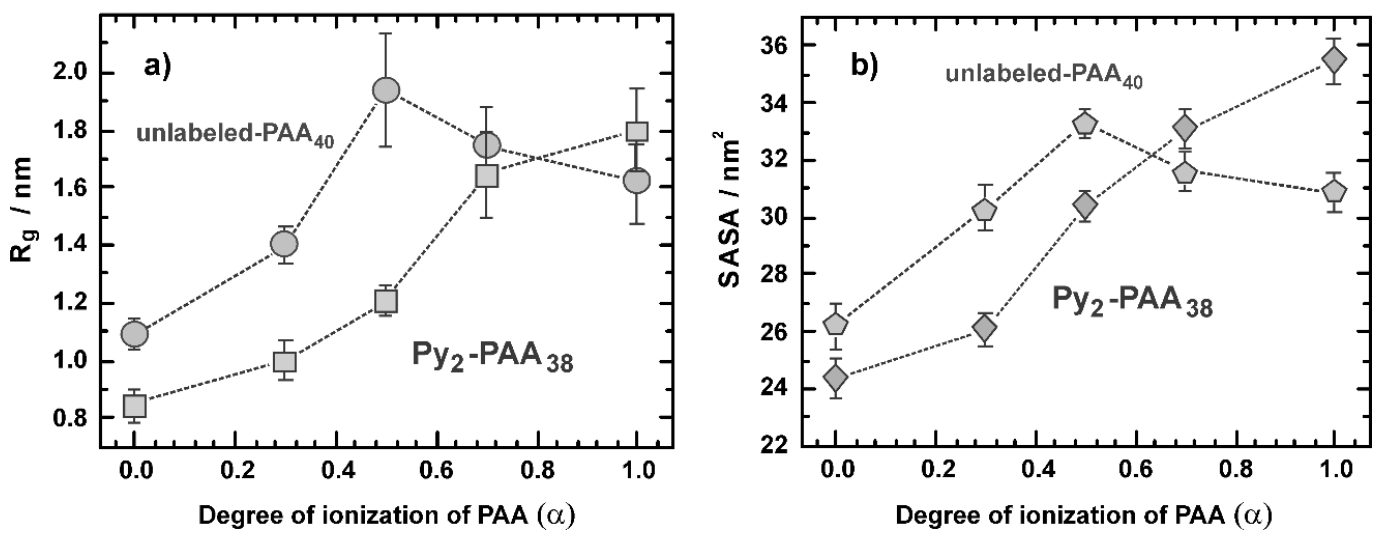

Fig. 4. Variations in the radius-of-gyration (a) and the solvent accessible surface area (b) with the degree of dissociation of the PAA chain for unlabeled-PAA and pyrene-labeled-PAA, respectively

\subsection{Solvent Accessibility Surface Area}

Since the polymer conformation could also affect solvent accessibility to the polymer chain, the solvent accessible surface area $(S A S A)$ was calculated by rolling a water probe across the van der Waals surface of PAA. The changes of $S A S A$ follow the similar trend to that of $R_{g}$ as shown in Fig. 4b. The $S A S A$ values show that the fully protonated and unprotonated pyrene-labeled $\mathrm{Py}_{2}-\mathrm{PAA}_{38}$ prefers to be in the globule and coil state, respectively.

\section{Conclusions}

Probing of structure and dynamics of water-soluble polymers with fluorescent dyes has several advantages over other spectroscopic techniques; however, the role of fluorescence dyes in polymer photophysics of dye-labeled polymers should not be underestimated. To test this hypothesis, we developed and validated an atomistic model for molecular dynamics (MD) simulations of poly(acrylic acid) (PAA), which was terminally labeled by the two pyrene dyes. This MD model allowed us to study the structure and conformational dynamics of pyrene-labeled PAA, as a function of a degree of dissociation $(\alpha)$ of the carboxyl groups $-\mathrm{COOH}$. By comparing the conformational behavior of unlabeled and pyrene-labeled $\mathrm{PAA}_{40}$, we found that the attachment of a pyrene dye to $\mathrm{PAA}_{40}$ alters significantly its conformational behavior. MD simulations revealed that at low $\mathrm{pH}(\alpha=0)$ the PAA chain collapsed into the random coil conformation due to the formation of the stable $\pi-\pi$ stacking structure by the two pyrene moieties. No such stacked pyrene dimer was formed at $\alpha=0.5$, because of partial dissociation of the polymer side-chain groups. The conformation of $\mathrm{Py}_{2}-\mathrm{PAA}_{38}$ macromolecule was expanded and the pyrene dyes were isolated inside hydrophobic microdomains formed by the polymer. Moreover, at high
$\mathrm{pH}(\alpha=1.0)$, the PAA chain was further expanded and stretched facing the pyrene dyes apart into aqueous solution. Finally, we showed that the pH-adaptive behavior of PAA makes its successful applications in novel generations of smart materials; however, fluorescent pyrene probes should be used with caution due to their hydrophobic nature.

\section{Acknowledgments}

This work was performed using computational facilities of the joint computational cluster of SSI "Institute for Single Crystals" and Institute for Scintillation Materials of National Academy of Science of Ukraine incorporated into Ukrainian National Grid. AK acknowledges help under Grant 0119U002536 of the Ministry of Education and Science of Ukraine.

\section{References}

[1] Duhamel J.: 7 - Pyrene Fluorescence to Study Polymeric Systems [in:] Chen P. (Ed.), Molecular Interfacial Phenomena of Polymers and Biopolymers. Woodhead Publishing, 2005, 214-248. https://doi.org/10.1533/9781845690830.2.214

[2] Saroj S., Rajput S.: Drug Dev. Ind. Pharm., 2018, 44, 1198. https://doi.org/10.1080/03639045.2018.1438467

[3] Wei M., Gao Y., Li X., Serpe M.: Polym. Chem., 2017, 8, 127. https://doi.org/10.1039/C6PY01585A

[4] Arora K., Hwang K., Turro N.: Macromolecues, 1986, 19, 2806. https://doi.org/10.1021/ma00165a025

[5] Kramer M., Steger J., Hu Y., McCormick C.: Macromolecules, 1996, 29, 1992. https://doi.org/10.1021/ma951087p

[6] Winnik F.: Chem. Rev., 1993, 93, 587.

https://doi.org/10.1021/cr00018a001

[7] Costa T., Miguel Md., Lindman B. et al.: J. Phys. Chem. B, 2005, 109, 11478. https://doi.org/10.1021/jp050236v

[8] Pokhrel M., Bossmann S.: J. Phys. Chem. B, 2000, 104, 2215. https://doi.org/10.1021/jp9917190

[9] Farhangi S., Casier R., Li L. et al.: Macromolecules, 2016, 49,

9597. https://doi.org/10.1021/acs.macromol.6b02455 
[10] Seixas de Melo J., Costa T., Miguel Md. et al.: J. Phys. Chem. B, 2003, 107, 12605. https://doi.org/10.1021/jp0346054

[11] Liu F., Urban M.: Prog. Polym. Sci., 2010, 35, 3. https://doi.org/10.1016/j.progpolymsci.2009.10.002

[12] Costa T., de Melo S., Castro C. et al.: J. Phys. Chem. B, 2010, 114, 12439. https://doi.org/10.1021/jp1020214

[13] Ramos J., Forcada J., Hidalgo-Alvarez R.: Chem. Rev., 2014, 114, 367. https://doi.org/10.1021/cr3002643

[14] Schmaljohann D.: Adv. Drug Delivery Rev., 2006, 58, 1655. https://doi.org/10.1016/j.addr.2006.09.020

[15] Wang S., Huang P., Chen X.: ACS Nano, 2016, 10, 2991. https://doi.org/10.1021/acsnano.6b00870

[16] Motornov M., Roiter Y., Tokarev I., Minko S.: Prog. Polym. Sci., 2010, 35, 174.

https://doi.org/10.1016/j.progpolymsci.2009.10.004

[17] Gao Y., Ahiabu A., Serpe M.: ACS Appl. Mater. Inter., 2014, 6, 13749. https://doi.org/10.1021/am503200p

[18] Feng N., Dong J., Han G., Wang G.: Macromol. Rapid Commun., 2014, 35, 721. https://doi.org/10.1002/marc.201300863

[19] Payne W., Svechkarev D., Kyrychenko A., Mohs A.:

Carbohydr. Polym., 2018, 182, 132.

https://doi.org/https://doi.org/10.1016/j.carbpol.2017.10.054

[20] Zhou X., Zhao K.: Phys. Chem. Chem. Phys., 2017, 19, 20559. https://doi.org/10.1039/C7CP02460F

[21] Qin S., Yong X.: Soft Matter., 2017, 13, 5137.

https://doi.org/10.1039/C7SM00637C

[22] Katiyar R., Jha P.: Polymer, 2017, 114, 266.

https://doi.org/10.1016/j.polymer.2017.03.007

[23] Sharma A., Smith J., Walters K., Rick S.: J. Chem. Phys., 2016,

145, 234906. https://doi.org/10.1063/1.4972062

[24] Patel K., Chockalingam R., Natarajan U.: Mol. Simul., 2017,

43, 691. https://doi.org/10.1080/08927022.2017.1295454

[25] Jha K., Desai S., Li J., Larson G.: Polymers, 2014, 6, 1414. https://doi.org/10.3390/polym6051414

[26] Reith D., Müller B., Müller-Plathe F., Wiegand S.: J. Chem. Phys., 2002, 116, 9100. https://doi.org/10.1063/1.1471901

[27] Chockalingam R., Natarajan U.: Mol. Simul., 2015, 41, 1110. https://doi.org/10.1080/08927022.2014.947481

[28] Sappidi P., Natarajan U.: J. Mol. Graphics Model., 2017, 75, 306. https://doi.org/https://doi.org/10.1016/j.jmgm.2017.04.007

[29] Sulatha M., Natarajan U.: Ind. Eng. Chem. Res., 2011, 50, 11785. https://doi.org/10.1021/ie2014845

[30] Kyrychenko A., Korsun O., Gubin I. et al.: J. Phys. Chem. C, 2015, 119, 7888. https://doi.org/10.1021/jp510369a

[31] Kyrychenko A., Pasko D., Kalugin O.: Phys. Chem. Chem. Phys., 2017, 19, 8742. https://doi.org/10.1039/C6CP05562A
[32] Berendsen H., Grigera J., Straatsma T.: J. Phys. Chem., 1987, 91, 6269. https://doi.org/10.1021/j100308a038

[33] Bussi G., Donadio D., Parrinello M.: J. Chem. Phys., 2007, 126, 014101/1. https://doi.org/10.1063/1.2408420

[34] Darden T., York D., Pedersen L.: J. Chem. Phys., 1993, 98, 10089. https://doi.org/10.1063/1.464397

[35] Hess B., Bekker H., Berendsen H., Fraaije J.: J. Comput. Chem., 1997, 18, 1463. https://doi.org/10.1002/(SICI)1096987X(199709)18:12<1463::AID-JCC4>3.0.CO;2-H

[36] Hess B.: J. Chem. Theory Comput., 2008, 4, 116. https://doi.org/10.1021/ct700200b

[37]Van Der Spoel D., Lindahl E., Hess B. et al.: J. Comput. Chem., 2005, 26, 1701. https://doi.org/10.1002/jcc.20291

[38] Humphrey W., Dalke A., Schulten K.: J. Mol. Graphics, 1996, 14, 33. https://doi.org/10.1016/0263-7855(96)00018-5

[39] Kyrychenko A.: Method. Appl. Fluoresc., 2015, 3, 042003/1. https://doi.org/10.1088/2050-6120/3/4/042003

[40] Laguecir A., Ulrich S., Labille J. et al.: Eur. Polym. J., 2006, 42, 1135. https://doi.org/10.1016/j.eurpolymj.2005.11.023

[41] Van Der Spoel D., Lindahl E., Hess B. et al.: Gromacs user manual version 4.5.4. www.gromacs.org, 2010.

[42] Svechkarev D., Kyrychenko A., Payne W., Mohs A.: Soft

Matter., 2018, 14, 4762. https://doi.org/10.1039/C8SM00908B

Received: May 07, 2018 / Revised: May 23, 2018 / Accepted: September 18, 2018

\section{БУДОВА ТА ДИНАМІКА ПІРЕН-МІЧЕНОЇ ПОЛІАКРИЛОВОЇ КИСЛОТИ: МОЛЕКУЛЯРНО- ДИНАМІЧНЕ МОДЕЛЮВАННЯ}

Анотація. Розроблено атомістичну модель для молекулярно-динамічного моделювання (МД) нерозгалуженої поліакрилової кислоти (ПАК), яка містить два піренові зонди на кінцях ланцњюга. За результатами МД моделювання будови та конформачійної поведінки пірен-міченої ПАК як функиіі

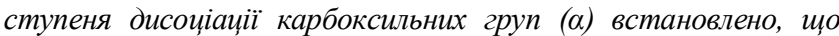
піренові замісники здатні суттєво впливати на конформаційну поведінку ПАК. При кислому рН $(\alpha=0)$ полімерний ланцюг ПАК згортається у форму глобули, при иьому два піренові замісника утворюють $\pi-\pi$ стекінгові дімери. Однак, в лужному $p H$ $(\alpha=1)$ ПАК ланцюг розгортається та вивільняє піренові зонди у водне середовище.

Ключові слова: поліакрилова кислота, пірен, флуоресиентний зонд, конформаиійна динаміка, молекулярнодинамічне моделювання. 